\title{
O wartości logicznej enigmatycznych odpowiedzi
}

\author{
On the logical value of enigmatic answers \\ Włodzimierz Lapis \\ Institute of Linguistics, Adam Mickiewicz University \\ Ul. Międzychodzka 5, 60-371 Poznań, POLAND
}

\begin{abstract}
The data discussed in the article have been collected from web pages and include sentences containing phrases: I don't confirm or I don't deny and compounds of both (also sentences containing synonymous phrases). The meaning of these sentences is discussed not only in their literal sense, but also in the intentional one (following the way of author's thinking) or in the interpretative one (how the meaning was understood by its recipient).
\end{abstract}

\section{Wprowadzenie}

W życiu codziennym coraz częściej spotykamy się z sytuacjami, gdy osoba pytana o to, „czy sytuacja ma się tak-a-tak?” daje enigmatyczną odpowiedź postaci nie potwierdzam lub nie zaprzeczam, czy też będącą złożeniem tych dwóch odpowiedzi (tj. np. postaci nie potwierdzam ani nie zaprzeczam). Jak często one padają? Przy pomocy jakich słów i wyrażeń są oddawane? Jaki ma to związek ze stanem faktycznym i z intencją osoby wypowiadającej te słowa co do zakresu odzwierciedlenia jej? Odnośnie jakich dziedzin są one używane (polityka, sport, gospodarka, nauka, inne)? W jakich sytuacjach się to dzieje? Czy są one ucieczką od wyrażenia prawdy czy tylko zamaskowaniem niewiedzy?

W oparciu o wiedzę autora niniejszego artykułu, żadne z tych zagadnień nie było dotychczas badane. Ponieważ jednak uznał on je za niezmiernie ciekawe, i to zarówno pod względem poznawczym, jak i możliwości praktycznego wykorzystania wyników ich analizy, w związku z powyższym wszystkie te zagadnienia poddał dokładnym badaniom, a następnie wyniki swej pracy ujął w niniejszym artykule.

Wszystkie dane do badań zaczerpnięte zostały z polskich zasobów Internetu na początku XI 2003 roku za pomocą wyszukiwarki www.szukacz.pl. Wybór takiej właśnie metody pozyskiwania danych został podyktowany jej prostotą i ogólną dostępnością.

\section{Opis wyrażeń prostych}

Tabela 1 zawiera zestawienia liczbowe wystapień w polskich zasobach Internetu słów z I kolumny (w pierwszej części oznaczających potwierdzenie, a w drugiej - zaprzeczenia) w ogóle (w II kolumnie) i z przedrostkiem nie (w IV kolumnie); a w III kolumnie podano ile razy występuja 
one $\mathrm{w}$ polskich zasobach Internetu bezpośrednio niepoprzedzone słowem nie. $\mathrm{W} \mathrm{V}$ kolumnie podano jaki procent wyników z II kolumny stanowią wyniki z IV kolumny (a więc z nie na początku w stosunku do wszystkich). Z kolei w kolumnie VI podano jaki odsetek wszystkich stanowią te, które nie wyrażają negatywnej sytuacji (tj. „potwierdzają” lub „nie zaprzeczają).

Tabela 1. Zestawienia wystapień poszczególnych słów $i$ wyrażeń w polskich zasobach Internetu

\begin{tabular}{|c|c|c|c|c|c|c|c|}
\hline \multirow{3}{*}{ LP } & \multirow{3}{*}{ słowo } & \multicolumn{5}{|c|}{ Wyniki } & \\
\hline & & \multirow[b]{2}{*}{ wszystkie } & \multicolumn{2}{|c|}{ w tym } & \multirow{2}{*}{$\begin{array}{c}\text { odsetek } \\
\text { z nie }\end{array}$} & \multirow{2}{*}{$\begin{array}{c}\text { odsetek } \\
\text { nienegatywnych } \\
\text { (zacieniowanych) }\end{array}$} & \multirow{16}{*}{$\begin{array}{l}\text { I część } \\
\text { (wyrażenia } \\
\text { o rdzeniu } \\
\text { pozytyw- } \\
\text { nym) } \\
\text { II część } \\
\text { (wyrażenia } \\
\text { o rdzeniu } \\
\text { negatyw- } \\
\text { nym) }\end{array}$} \\
\hline & & & $\begin{array}{l}\text { bez nie na } \\
\text { początku }\end{array}$ & $\begin{array}{l}\mathrm{z} \text { nie na } \\
\text { początku }\end{array}$ & & & \\
\hline & I & II & III & IV & $\mathrm{V}$ & VI & \\
\hline 1 & potwierdzam & 19180 & 18512 & 668 & $3,48 \%$ & $96,52 \%$ & \\
\hline 2 & popieram & 55981 & 51746 & 4235 & $7,57 \%$ & $92,43 \%$ & \\
\hline 3 & twierdzę & 19413 & 11849 & 7594 & $39,12 \%$ & $60,88 \%$ & \\
\hline \multirow[t]{2}{*}{4} & zapewniam & 27243 & 27103 & 140 & $0,51 \%$ & $99,49 \%$ & \\
\hline & RAZEM & 121817 & 109180 & 12637 & $10,37 \%$ & $89,63 \%$ & \\
\hline 5 & zaprzeczam & 3543 & 1090 & 2453 & $69,24 \%$ & $69,24 \%$ & \\
\hline 6 & oponuję & 64 & 45 & 19 & $29,69 \%$ & $29,69 \%$ & \\
\hline 7 & wykluczam & 4965 & 1051 & 3914 & $78,83 \%$ & $78,83 \%$ & \\
\hline 8 & obalam & 250 & 244 & 6 & $2,40 \%$ & $2,40 \%$ & \\
\hline 9 & neguję & 1408 & 155 & 1253 & $88,99 \%$ & $88,99 \%$ & \\
\hline \multirow[t]{3}{*}{10} & dementuję & 799 & 750 & 49 & $6,13 \%$ & $6,13 \%$ & \\
\hline & RAZEM & 11029 & 3335 & 7694 & $70,30 \%$ & $74,73 \%$ & \\
\hline & OGÓLEM & 132846 & 112515 & 20331 & $15,30 \%$ & $87,98 \%$ & \\
\hline
\end{tabular}

Jak wyraźnie widać z powyższej tabeli, w polskich zasobach Internetu zdecydowanie częściej występują słowa „potwierdzające” (tj. z I części) niż „,negujące” (tj. z II części) - w powyższym zestawieniu aż ok. 11 razy, gdyż: 121817 / $11029 \approx 11,05$.

Analogicznie wyrażenia „nienegatywne” (kolumna VI) stanowią też zdecydowaną większość $(87,98 \%)$ ogółu rozpatrywanych wyrażeń.

Przypatrzmy się obecnie liczbom zapisanym w inwersie. Na poniższym diagramie podane sa $\mathrm{w}$ analogicznym rozmieszczeniu, jednak dodatkowo zaopatrzone stosownym opisem.

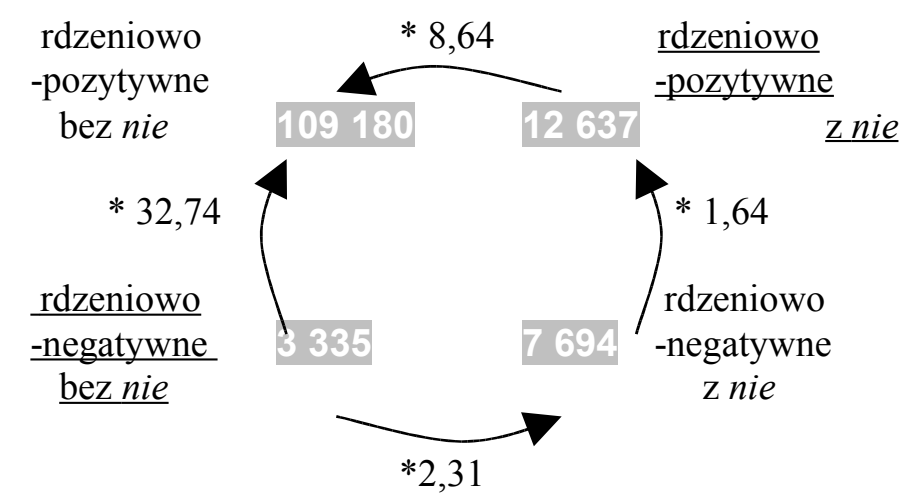

Diagram 1. Zależności liczebne między poszczególnymi typami wyrażeń prostych 
Jak widać z diagramu 1, wyrażeń rdzeniowo-pozytywnych jest więcej od rdzeniowo-negatywnych, i to zarówno gdy występują one jako pojedyncze słowa, jak i wtedy gdy owe słowa występują w konkatenacji z nie (strzałki pionowe na powyższym diagramie - o odpowiednio 32,74 i 1,64 raza częściej). Spróbujmy wytłumaczyć te zależności. Sytuacja taka spowodowana jest zapewne faktem, że rozmówcy wolą stosować wyrażenie rdzeniowo-pozytywne od rdzeniowo-negatywnych. Jest to dosyć praktyczne, gdyż stosując wyrażenie rdzeniowo-pozytywne, mamy klarowną i zarazem naturalną sytuację: stwierdzenie bez negacji znaczy TAK, a z negacją NIE. Z kolei w przypadku stosowania stwierdzeń rdzeniowo-negatywnych jest na odwrót, a więc nienaturalnie, a nadto - dla przeciętnego użytkownika - w przypadku stwierdzeń rdzeniowo-negatywnych $\mathrm{z}$ negacją dochodzi problem jak rozumieć występujące w nim podwójne przeczenie.

Zauważmy jeszcze, że stosunek pierwszej z powyższych zależności (a więc odnoszących się do wyrażeń bez nie) do drugiej z nich (a więc odnoszących się do wyrażeń z nie) wynosi aż 32,74 / $1,64 \approx 19,96$. Zapewne wynika to nie tyle $\mathrm{z}$ małej liczby wyrażeń rdzeniowo-negatywnych bez nie, ile raczej ze stosunkowo dużej liczby wyrażeń rdzeniowo-negatywnych z nie. Dodajmy, że wyrażenia rdzeniowo-negatywne z nie, to znaczeniowo prawie to samo co rdzeniowo-pozytywne bez nie, a tych (jak wiemy) jest najwięcej. Łącznie nazwijmy je potencjalnie-pozytywnymi (na diagramie oznaczone je bez podkreślenia).

Zauważmy od razu, że i wyrażenia rdzeniowo-negatywne bez nie i rdzeniowo-pozytywne z nie również wyrażają prawie to samo (stąd też - analogicznie jak powyżej - możemy je nazwać potencjalnie-negatywnymi; na diagramie 1 zostały one oznaczone podkreśleniem). Widzimy ponadto, że na diagramie tym strzałki poziome zawsze „idą” od wyrażeń potencjalnienegatywnych (podkreślonych) do wyrażeń potencjalnie-pozytywnych (niepodkreślonych). Oznacza to, że wyrażeń potencjalnie-pozytywnych jest zawsze (tj. niezależnie od tego, w jakiej postaci są podane) więcej od wyrażeń potencjalnie-negatywnych (stworzonych w oparciu o nie, poprzez dodanie lub odjęcie słowa nie). Wythumaczenie tego faktu jest identyczne $\mathrm{z}$ zastosowanym $\mathrm{w}$ poprzednim akapicie.

Do powyższych wniosków można dojść również analizując dwie ostatnie kolumny w tabeli 1 . Kolumna V świadczy o tym, że określenia z nie stanowią 15,30 \% wszystkich, a kolumna VI, że potencjalnie-pozytywne $87,98 \%$ wszystkich.

\section{Wartość logiczna wyrażeń prostych}

W poprzednim paragrafie wyróżniliśmy 4 kategorie „wyrażeń prostych”:

1) rdzeniowo-pozytywne bez nie: potwierdzam, popieram, twierdze, zapewniam;

2) rdzeniowo-negatywne bez nie: zaprzeczam, oponuje, wykluczam, obalam, neguje, dementuje;

3) rdzeniowo-pozytywne z nie (jak w 1), lecz poprzedzone przez nie);

4) rdzeniowo-negatywne $\mathrm{z}$ nie (jak w 2), lecz poprzedzone przez nie).

Pierwsze dwie kategorie nie wymagają większego wyjaśnienia - jest oczywiste, że gdy wypowiadamy twierdzenia ich typu (przy założeniu, że nie kłamiemy), to:

- w I przypadku - zgadzamy się z pewnym stanem rzeczy,

- $\quad$ w II przypadku - nie zgadzamy się z nim.

Gorzej ma się sprawa w przypadku pozostałych dwóch kategorii.

1) W przypadku kategorii trzeciej - wyrażenia nie potwierdzam, nie popieram, nie twierdzę i nie zapewniam, przy założeniu, że wypowiadająca je osoba mówi prawdę, wcale nie muszą znaczyć, że de facto jest tak, jak ona mówi. Może ona bowiem np. „nie potwierdzać” zewnętrznie (słownie), a czynić tak jedynie wewnętrznie (,w głębi duszy”).

2) Podobnie jest w przypadku kategorii czwartej. Wyrażenia nie zaprzeczam, nie oponuje, nie wykluczam, nie obalam, nie neguje, czy nie dementuje, przy założeniu, że wypowiadająca je osoba mówi prawdę, wcale nie muszą znaczyć, że de facto jest tak, jak ona mówi. Może ona bowiem np. „nie negować” zewnętrznie (słownie), a czynić tak jedynie wewnętrznie („w głębi duszy"). Co niezmiernie istotne, dochodzi tu jeszcze jeden bardzo ważny aspekt. Mamy tu bowiem do czynienia z podwójnym przeczeniem (bo „nie negować” = „nie nie-potwierdzać”). 
Jednak w przypadku tym wyrażenie tego typu bynajmniej nie musi oznaczać potwierdzenia, lecz np. coś pośredniego (np.: „Nie potwierdzam, ani nie neguję, bo wcale się na tym nie znam”). Logiczna zasada podwójnego przeczenia nie musi się więc tu stosować (i często, a nawet najczęściej, tak jest).

\section{Opis wyrażeń złożonych}

Rozpatrzmy występujące w polskich zasobach Internetu wyrażenia będące złożeniem - nie popieram $\mathrm{z}$ nie zaprzeczam (tabela 2),

- i nie popieram z nie dementuje (tabela 3).

Tabela 2. Ztożenie ,nie popieram” $z$,nie zaprzeczam”

\begin{tabular}{|c|c|c|c|}
\hline wiersz & układ & (A) $\sim \mathrm{P}(\mathrm{A}) \sim \mathrm{Z}$ & (A) $\sim Z(\mathrm{~A}) \sim \mathrm{P}$ \\
\hline 1 & $\overline{\mathrm{AA}}$ & $14 \quad(1)$ & 14 \\
\hline 2 & $\mathrm{~A}(-)$ & 2 & - \\
\hline 3 & $(-) \mathrm{A}$ & 119 & 23 \\
\hline 4 & $(-)(-)$ & 185 & 22 \\
\hline \multicolumn{2}{|c|}{ RAZEM } & 320 & 59 \\
\hline
\end{tabular}

Tabela 3. Zlożenie ,nie popieram” $z$,,nie dementuje”

\begin{tabular}{|c|c|c|c|}
\hline wiersz & układ & $(\mathrm{A}) \sim \mathrm{P}(\mathrm{A}) \sim \mathrm{D}$ & $(\mathrm{A}) \sim \mathrm{D}(\mathrm{A}) \sim \mathrm{P}$ \\
\hline 1 & $\mathrm{AA}$ & 1 & - \\
\hline 2 & $\mathrm{~A}(-)$ & - & - \\
\hline 3 & $(-) \mathrm{A}$ & 5 & 4 \\
\hline 4 & $(-)(-)$ & 1 & - \\
\hline \multicolumn{2}{|c|}{ RAZEM } & 7 & 4 \\
\hline
\end{tabular}

Występujące w tych tabelach symbole oznaczają:

- A - ani,

- $\quad \mathrm{P}$ - popieram,

- Z-zaprzeczam,

- $\quad \mathrm{D}$ - dementuje,

- $\sim$-nie.

Ponadto, w tabelach tych:

- w nagłówkach kolumn, A jest w nawiasach, dla oznaczenia, że jedynie może w tych miejscach wystapić słowo ani,

- zaś A występujące w nagłówkach wierszy oznacza, że na danej pozycji ani występuje, a (-) że nie.

Wewnątrz tabeli 2, w 3 polach dodatkowo zaznaczono (w nawiasach okragłych) ile wyrażeń o omawianej strukturze istnieje „zanieczyszczonych” dodatkowymi słowami. Poniżej wypisano jaką przyjmują one postać:

(1): Nie potwierdził $\underline{\text { i nie zaprzeczył. }}$

$(1 \mathrm{raz})$,

(2): Ani nie potwierdzam i nie zaprzeczam.

(2 razy),

(3): Nie potwierdzam niczego ani nie zaprzeczam.

$(1 \mathrm{raz})$,

Nie potwierdzam więc ani nie zaprzeczam.

$(1 \mathrm{raz})$,

Nie potwierdzam tego że (...) ani nie zaprzeczam. (1 raz),

(6): Nie zaprzeczam tej teorii ani nie potwierdzam.

(6 razy).

$\mathrm{Z}$ analizy tabel nr 2 i 3 wyciaggamy następujące dwa wnioski: 
1) ani raczej w tych wyrażeniach nie występuje, a szczególnie na I pozycji (wiersze 3 i $4 \mathrm{w}$ obu tych tabelach),

2) w rozpatrywanych tu wyrażeniach, zdecydowanie częściej (w tabeli 2: 319 / 59 $\approx 5,41$ raza, a w tabeli 3: $7 / 4=1,75$ raza) słowo popieram występuje przed słowem zaprzeczam (w tabeli 2 ) lub dementuje (w tabeli 3).

Przyjrzyjmy się obecnie uważniej wypowiedzeniom (słowo użyte w tej formie ze względu na rozróżnienie od wprowadzonej poniżej „wypowiedzi”), które posłużyły do skonstruowania tabel 2 i 3. W tym celu wyszczególniliśmy 6 typów owych wypowiedzeń:

- $\quad$ T - tytuł,

- I- wywiad,

- O - odpowiedź,

- W- wypowiedź,

- $\quad \mathrm{R}$ - relacja (= W o O lub z zacytowaną O innej osoby),

- $\mathrm{S}$ - opowiadanie.

W tabeli 3 były to wypowiedzenia:

W I kolumnie z danymi (wszystkie są W):

1) O zamiarze zakończenia przez Ignacoka dowiedziałem się niedawno $z$ radia $i$ ani nie potwierdzam, ani nie dementuje tej pogłoski.

2) No co, ponoć człowiek na trzeźwo też może się bawić, nie potwierdzam, nie dementuję .. takiego stanu jak trzeźwe myślenie nie znam.

3) Mówi się (sam tego nie próbowałem, więc nie potwierdzam ani nie dementuję), że można ten problem załatwić kupując jaką́s tuleję, lub (...) raz),

W II kolumnie z danymi (wszystkie są O):

4) Info o światłowodzie nie dementuje ani nie potwierdzam.

(4 razy).

Tak więc wszystkie $\mathrm{W}$ najpierw odnoszą się do potwierdzania, a potem do dementowania. $\mathrm{Z}$ kolei wszystkie $\mathrm{O}$ na odwrót: najpierw odnoszą się do dementowania, a potem do potwierdzania.

Aby dokonać analogicznej analizy danych zawartych w tabeli $\mathbf{2}$, ponumerujmy występujące w niej zacieniowane pola $\mathrm{z}$ danymi: najpierw pierwszą kolumnę od góry do dołu (odpowiednio liczbami od 1 do 4), a następnie drugą kolumnę też od góry do dołu (tu odpowiednio liczbami od 5 do 8). Teraz wyniki tej analizy można już zaobserwować w poniższym zestawieniu (tabela 4).

Tabela 4. Charakterystyka ilościowa kategorii wypowiedzeń rozważanych w poszczególnych polach tabeli 2

\begin{tabular}{|c|c|c|c|c|c|c|c|c|c|c|}
\hline \multicolumn{2}{|c|}{} & \multicolumn{7}{|c|}{ numer pola z danymi w tabeli 2} & RA- \\
\cline { 2 - 12 } & 1 & 2 & 3 & 4 & 5 & 6 & 7 & 8 & ZEM \\
\hline ka & T & & & 3 & 5 & & & & 5 & 13 \\
te & $\mathrm{I}$ & 3 & & 18 & 19 & 1 & & & 1 & 42 \\
go & $\mathrm{O}$ & 1 & 2 & 13 & 46 & & & 1 & 5 & 68 \\
ria & $\mathrm{W}$ & 1 & & 38 & 18 & & & 10 & 7 & 74 \\
w & $\mathrm{R}$ & 9 & & 47 & 96 & 13 & & 12 & 4 & 181 \\
yp & $\mathrm{S}$ & & & & & & & & & \\
o \\
wi & & & & & & & & & & \\
ed & & & & & 1 & & & & & 1 \\
ze & & & & & & & & & & \\
ń & & & & & & & & & & \\
\hline \multicolumn{2}{|c|}{ RAZEM } & 14 & 2 & 119 & 185 & 14 & 0 & 23 & 22 & 379 \\
\hline
\end{tabular}


Wnioskujemy z niej, że tego typu wypowiedzenia występują najczęściej w relacjach (181 razy prawie połowa wszystkich przypadków), następnie w wypowiedziach (74 razy), odpowiedziach (68 razy) i wywiadach (41 razy), a najmniej w tytułach (13 razy) i opowiadaniu (1 raz).

$\mathrm{Z}$ kolei w poniższych dwóch tabelach (nr 5 i 6 ) podano, jakie dopowiedzenia dodane są do naszych wyrażeń: w tabeli 5 - odnośnie relacji (odnosi się więc ona do zacieniowanego wiersza tabeli 4), a w tabeli 6 - odnośnie pozostałych typów wypowiedzeń. Występująca w tabeli $5 \lambda$ (czyt.: lambda) oznacza słowo puste, a więc brak kontekstów.

Tabela 5. Ilościowa analiza kontekstów $R$ z tabeli 4

\begin{tabular}{|c|c|c|c|c|c|c|c|c|c|c|}
\hline \multirow[b]{2}{*}{ Kontekst } & \multicolumn{8}{|c|}{ numer pola $\mathrm{z}$ danymi $\mathrm{w}$ tab. 2} & \multirow{2}{*}{$\begin{array}{l}\text { SU- } \\
\text { MA }\end{array}$} & \multirow{2}{*}{$\begin{array}{c}\text { suma kategorii } \\
\text { czasownika }\end{array}$} \\
\hline & 1 & 2 & 3 & 4 & 5 & 6 & 7 & 8 & & \\
\hline lakonicznie odpowiada & 1 & & & & & & & & 1 & \multirow{8}{*}{29} \\
\hline odpowiedział jedynie & 2 & & & & & & & & 2 & \\
\hline enigmatycznie odpowiada & & & 3 & & & & & & 3 & \\
\hline Odpowiada & & & 11 & 6 & 5 & & 1 & 1 & 19 & \\
\hline 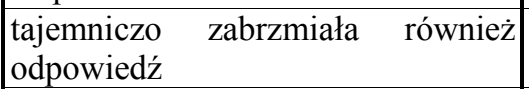 & & & & 1 & & & & & 1 & \\
\hline dwuznaczna odpowiedź & & & & 1 & & & & & 1 & \\
\hline udziela znanej odpowiedzi & & & & 1 & & & & & 1 & \\
\hline odpowiada z uśmiechem & & & & 1 & i] & & & & 1 & \\
\hline Powiedział & 1 & & 10 & 24 & & & 3 & 3 & 41 & \multirow{3}{*}{44} \\
\hline tylko tyle miał do powiedzenia & & & & 2 & & & & & 2 & \\
\hline tyle miał do powiedzenia & & & & 1 & 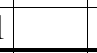 & & & & 1 & \\
\hline Mówi & 1 & & 8 & 26 & 4 & 4 & 1 & 1 & 40 & \multirow{3}{*}{45} \\
\hline tajemniczo mówi & & & & 2 & 2 & & & & 2 & \\
\hline mówił z uśmiechem & & & & 3 & 3 & & & & 3 & \\
\hline odparł & 1 & & & 1 & 1 & & & & 2 & \multirow[t]{2}{*}{4} \\
\hline odparł klasyczną formułą & & & 2 & & & & & & 2 & \\
\hline posługuje się formułą & & & & 1 & 1] & & & & 1 & 1 \\
\hline użył frazy & & & & {$[1$} & 4 & 4 & & & 4 & 4 \\
\hline Skomentował & & & 3 & 4 & 4 & & 5 & 5 & 12 & \multirow{3}{*}{18} \\
\hline nie chce komentować & & & & 1 & 1 & & & & 1 & \\
\hline Komentuje & & & 2 & 3 & 3 & & & & 5 & \\
\hline Ucina & & & & & & & 2 & 2 & 2 & \multirow[t]{2}{*}{4} \\
\hline ucina krótko & & & & 2 & 2 & & & & 2 & \\
\hline wygłasza sentencję & & & 1 & & & & & & 1 & 1 \\
\hline Dodaje & & & 1 & & & & & & 1 & 1 \\
\hline stwierdził lakonicznie & & & 1 & & & & & & 1 & \multirow{3}{*}{6} \\
\hline Stwierdził & & & 2 & 2 & 2 & & & & 4 & \\
\hline stwierdził tylko & & & & 1 & 1 & & & & 1 & \\
\hline Żartował & & & 1 & & & & & & 1 & 1 \\
\hline ujął całą sprawę & & & & 1 & 1 & & & & 1 & 1 \\
\hline Usłyszeliśmy & & & & 2 & 2 & & & & 2 & 2 \\
\hline Deklaruje & & & & 2 & 2 & & & & 2 & 2 \\
\hline Skwitowal & & & & 4 & 4 & & & & 4 & 4 \\
\hline$\lambda$ & 3 & & 2 & 4 & 5 & 5 & & & 14 & 14 \\
\hline S U M A & 9 & 0 & 47 & 96 & \begin{tabular}{|l|l|}
5 & 13 \\
\end{tabular} & \begin{tabular}{|l|l|}
3 & 0 \\
\end{tabular} & 12 & \begin{tabular}{l|l}
2 & 4 \\
\end{tabular} & \begin{tabular}{|l|l|}
4 & $181 \mid$
\end{tabular} & 181 \\
\hline
\end{tabular}


Tabela 6. Typy pozostałych kontekstów z tabeli 4

\begin{tabular}{|l|c|c|}
\hline \multirow{2}{*}{ kontekst } & \multicolumn{2}{c|}{ typ wypowiedzeń } \\
\cline { 2 - 3 } & $\mathrm{W}$ & $\mathrm{O}$ \\
\hline chciałoby się odpowiedzieć dyplomatycznie & 1 & \\
\hline Odpowiedział & 1 & \\
\hline odpowiedź brzmi & & 1 \\
\hline Mówi & 1 & \\
\hline mogę tylko dyplomatycznie stwierdzić & 2 & \\
\hline Powiedziała & 1 & \\
\hline SUMA & 6 & 1 \\
\hline
\end{tabular}

Przypatrzmy się bliżej tabeli 5. Występujące w niej stwierdzenia nazywane są mianem:

- frazy (4 razy),

- $\quad$ sekwencji

(1 raz),

- odpowiedzi

(3 razy),

- formuły

(3 razy).

Często akcentowane są ich lakoniczność i podawanie ich „na odczepne”. Możemy się o tym przekonać poprzez występujące w nich przymiotniki:
- lakonicznie
(2 razy),

- tylko

(3 razy),

- jedynie

(2 razy),

- krótko

(2 razy).

Wypowiedzenia tego typu są trudne do zinterpretowania, jako że są:

- enigmatyczne (3 razy),

- tajemnicze (3 razy).

Warto też zwrócić uwagę na fakt, że w zestawieniu tym współistnieją wyrażenia przeciwstawne:

- skomentował (12 razy),

- nie chciał komentować (1 raz).

Przytoczone powyżej 4 dopowiedzenia niosą ze sobą również bezpośrednią informację o niechęci wyrażania się przez wypowiadającą je osobę.

Zbadajmy jeszcze, jakie czasowniki (czy też w jednym przypadku: wyrażenie czasownikowe) występują w wypowiedzeniach z poszczególnych kolumn z tabeli 5. Otóż:

- w kolumnie nr 1: odpowiada, mówi, odpiera;

- w kolumnie nr 5: mówi, używa frazy;

- w kolumnie nr 7: odpowiada, mówi, komentuje i ucina;

- w kolumnie nr 8: odpowiada, mówi;

- w kolumnach nr 2 i 6: brak;

- w kolumnach nr 3 i 4: prawie wszystkie występujące w tej tabeli.

Oprócz ujętych w tabelach 2 i 3 oddań faktu, że wypowiadająca je osoba ,ani nie potwierdza ani nie zaprzecza" (czy też ,ani nie potwierdza, ani nie dementuje"), spotykamy się z nimi w polskich zasobach Internetu jeszcze w następujących stwierdzeniach (występujących jednak już tylko pojedynczo; poniżej, zaraz za nimi, podano ich typy):

I. W pierwszej cześci ,ani nie potwierdzam” jest skonfrontowane z wykluczaniem, obalaniem i ,wiadomo czym” - to oddane przez wielokropek (wszystkie po 1 raz):

1) Ani nie potwierdzam, ani nie wykluczam. R, 
2) Ani nie potwierdzam ani ...:).

$\mathrm{O}$

3) Ani tej tezy nie obalam ani nie potwierdzam.

$\mathrm{O}$;

II. W drugiej części , ani nie zaprzeczam” jest skonfrontowane z popieraniem, twierdzeniem, i zapewnianiem (również wszystkie po $1 \mathrm{raz}$ ):

1) Nie popieram ani nie zaprzeczam.

2) Nie twierdzę ani nie zaprzeczam.

3) Nie zapewniam ani nie zaprzeczam.

$\mathrm{O}$

$\mathrm{W}$;

W.

\section{Wartość logiczna wyrażeń złożonych}

Ze względu na wymogi statystyczne (konkretnie - ze względu na liczebność materiały badawczego), do tego typu badań, nadają się jedynie te wyrażenia, które są złożeniem nie popieram z nie popieram (a więc wcześniej zestawione już w tabeli 2 i 4 - 379 sztuk).

Poniżej wypisujemy je wszystkie w dwóch tabelach:

○ $\mathrm{w}$ tabeli 7 - te, w których najpierw występuje fraza nie potwierdzam, a potem nie zaprzeczam,

○ w tabeli $8-$ w odwrotnej kolejności.

Zastosowano w nich następujące oznaczenia:

- na oznaczenie typu: T, I, O, W, R i S - jak w paragrafie 3;

- w kolumnie ,tekst”:

- X-em zastapiono rozpatrywana frazę (dla przejrzystości tekstu), przy czy jeśli fraza ta ma w sobie jeszcze inne słowa (oprócz: nie, potwierdzam, zaprzeczam, ani) - to przytoczono ją całą a słowa, które zostały przytoczone w poprzednim nawiasie podkreślono,

- $\quad$ w inwersie podano te fragmenty wypowiedzi, które są znaczące do określenia wartości logicznej rozpatrywanej frazy,

- w nawiasach kwadratowych ([...]) ujęto dopowiedzenia autora niniejszego artykułu, oddające kontekst, dzięki któremu nożna określić szukaną wartość logiczną,

- / - rozdziela wypowiedzi dwóch rozmówców;

- liczba w kolumnie „ile” oznacza krotność wystąpienia danego tekstu w polskich zasobach Internetu.

Z kolei w trzech ostatnich kolumnach tych dwóch tabel podano hipotetyczne (gdyż jedynie według intuicyjnego rozumienia autora niniejszego tekstu) znaczenia tego typu wypowiedzeń:

- „X” w kolumnie „WNP” oznacza, że jej autor poprzez nią daje znać: „wiem, nie powiem” („bo nie chcę”, „bo nie moge” lub „bo nie powinienem” - tego jednak już nie rozpatrywano, ze względu na większe prawdopodobieństwo popełnienia błędu podczas analizy, z którym z tych przypadków mamy do czynienia);

- „X” w kolumnie „NP” oznacza, że jej autor poprzez nią daje znać: „nie powiem”,

- $\quad$ w kolumnie ,?" - poszczególne symbole oznaczają:

- , ", - raczej tak,

- ",+" - być może,

- " ,-" - raczej nie,

- „0” - trudno rozeznać które (,wiem, nie powiem”, czy „nie wiem”).

Tak więc $\mathrm{w}$ każdym $\mathrm{z}$ wierszy tych tabel (oprócz ich nagłówków) dokładnie $\mathrm{w}$ jednym polu $\mathrm{z}$ trzech ostatnich kolumn musi coś się pojawić.

Tabela 7. Analiza logiczna tekstów z fraza „,nie potwierdzam, nie zaprzeczam” (z ewentualnymi wtraceniami)

\begin{tabular}{||l|l|l|l|l|l|l||}
\hline \hline Lp & typ & Tekst & ile & WNP & NW & $?$ \\
\hline \hline 1 & $\mathrm{O}$ & Hmmm... a co do świn ani nie potwierdzam nie zaprzeczam! & 2 & & & + \\
\hline 2 & $\mathrm{O}$ & $\mathrm{X}$ & 11 & & & 0 \\
\hline 3 & $\mathrm{O}$ & Hehe, X. & 7 & $\mathrm{X}$ & & \\
\hline
\end{tabular}




\begin{tabular}{|c|c|c|c|c|c|c|}
\hline 4 & $\mathrm{O}$ & Hmm.... X & 3 & $\mathrm{X}$ & & \\
\hline 5 & $\mathrm{O}$ & Hm...., odpowiedź brzmi: $\mathrm{X}$; & 1 & & & $+{ }^{\prime}$ \\
\hline 6 & $\mathrm{O}$ & X. Można snuć domysły. Ja nikogo nie wskazywałem. & 1 & & & + \\
\hline 7 & $\mathrm{O}$ & [mówiąc] liezykiem dyplomacil - X & 1 & $\mathrm{X}$ & & \\
\hline 8 & $\mathrm{O}$ & Anguś nie bredź, $\mathrm{X}$ & 3 & & & 0 \\
\hline 9 & $\mathrm{O}$ & Nie potwierdzam... nie zaprzeczam... & 1 & & & $+{ }^{\prime}$ \\
\hline 10 & $\mathrm{O}$ & X. [na to komentarz kogoś innego:] wiec coś w tym jest :) & 1 & & & + \\
\hline 11 & $\mathrm{O}$ & $\mathrm{X}$ bo tam nie byłem & 11 & & $\mathrm{X}$ & \\
\hline 12 & $\mathrm{O}$ & X. Proszę dzwonić do Leona Pierwotniaka! & 2 & $\mathrm{X}$ & & \\
\hline 13 & $\mathrm{O}$ & $\begin{array}{l}\text { Czyżby wykluło się cos nowego? (...) / X / Czyli ,wykluło się coś } \\
\text { nowego". }\end{array}$ & 3 & & & + \\
\hline 14 & $\mathrm{O}$ & $\begin{array}{l}\text { A więc powiem to tak: X, po prostu nie ma co robić sensacji, a nad } \\
\text { propozycją jeszcze się zastanawiam. }\end{array}$ & 7 & & & + \\
\hline 15 & $\mathrm{O}$ & $\begin{array}{l}\text { Hm... guru ideałem? Niech pomyślę...Heh, lepiej znów } \\
\text { dyplomatycznie: } X\end{array}$ & 1 & & & - \\
\hline 16 & $\mathrm{O}$ & X. W każdym razie Monika ucieszyła sie z pozdrowien ;)) & 1 & & & - \\
\hline 17 & $\mathrm{O}$ & $\begin{array}{l}\text { A może po prostu jestem ciemny ... / Powiem tak... Nie potwierdzam- } \\
\text { nie zaprzeczam. Ale gratuluje za odwage przyznania się do swojej } \\
\text { ułomności }\end{array}$ & 6 & & & + \\
\hline 18 & $\mathrm{R}$ & $\begin{array}{l}\text { Zobowiazaliśmy sie do zachowania nazwy banku w tajemnicy. Nie } \\
\text { potwierdzam więc ani nie zaprzeczam }\end{array}$ & 1 & & & + \\
\hline 19 & $\mathrm{R}$ & 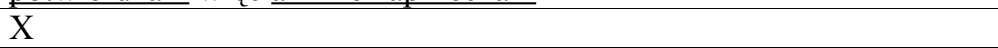 & 80 & & & 0 \\
\hline 20 & $\mathrm{R}$ & $\mathrm{X}$ - odpowiada $\mathrm{z}$ uśmiechem & 1 & & & + \\
\hline 21 & $\mathrm{R}$ & $\mathrm{X}$ - mówił $z$ uśmiechem na temat spekulacji & 3 & & & + \\
\hline 22 & $\mathrm{R}$ & X. I proszę z mojej wypowiedzi nie wyciagać wniosków. & 1 & & & 0 \\
\hline 23 & $\mathrm{R}$ & X. Ale z tego nie można wyciagać żadnych wniosków. & 3 & & & 0 \\
\hline 24 & $\mathrm{R}$ & $\mathrm{X}$ i proszę z tego nie wyciągać żadnych wniosków. & 1 & & & 0 \\
\hline 25 & $\mathrm{R}$ & Dziśs moge powiedzieć tylko tyle, że X tej informacji. & 1 & & & + \\
\hline 26 & $\mathrm{R}$ & $\mathrm{X}$ tej informacji. & 4 & & & 0 \\
\hline 27 & $\mathrm{R}$ & Nie jestem kompetentny, więc X. - wygłasza sentencję & 1 & $\mathrm{X}$ & & \\
\hline 28 & $\mathrm{R}$ & $\begin{array}{l}\text { Potwierdzam, że Emmanuel był w Monachium. X, że jest w } \\
\text { Panathinaikosie. }\end{array}$ & 1 & & & + \\
\hline 29 & $\mathrm{R}$ & X. Obowiazuje mnie tajemnica śledztwa. & 1 & $\mathrm{X}$ & & \\
\hline 30 & $\mathrm{R}$ & $\begin{array}{l}\text { Nie chciał potwierdzić ani faktu głosowania, ani jego wyników - X - } \\
\text { stwierdził. }\end{array}$ & 1 & & & + \\
\hline 31 & $\mathrm{R}$ & Odparł klasyczną formułą: „X...” & 2 & & & 0 \\
\hline 32 & $\mathrm{R}$ & $\mathrm{X}$, że jest moja - żartowal & 1 & & & + \\
\hline 33 & $\mathrm{R}$ & Proszony o potwierdzenie informacji powiedział: - X & 1 & & & 0 \\
\hline 34 & $\mathrm{R}$ & $\mathrm{X}$, nic więcej w tej kwestii nie mam do powiedzenia. & 1 & $\mathrm{X}$ & & \\
\hline 35 & $\mathrm{R}$ & $\mathrm{X}$, nic więcej w tej kwestii nie powiem. & 1 & $\mathrm{X}$ & & \\
\hline 36 & $\mathrm{R}$ & X. Muszę się nad tym poważnie zastanowić. & 4 & & $\mathrm{X}$ & \\
\hline 37 & $\mathrm{R}$ & X. Skoro tak podaje „Sport” to widać coś w tym musi być. & 2 & & & + \\
\hline 38 & $\mathrm{R}$ & Trudno powiedzieć, skoro rozmowy trwaja. X & 1 & & $\mathrm{X}$ & \\
\hline 39 & $\mathrm{R}$ & $\mathrm{X}$ - powiedział nam nasz drugi informator & 1 & & $\mathrm{X}$ & \\
\hline 40 & $\mathrm{R}$ & Na to pytanie jest taka dobra odpowiedź: $\mathrm{X}$ & 2 & & & 0 \\
\hline 41 & $\mathrm{R}$ & $\begin{array}{l}\text { Ministerstwo Finansów, pytane } 0 \text {,interwencje", nabrało wody w usta. } \\
-X\end{array}$ & 1 & & & + \\
\hline 42 & $\mathrm{R}$ & $\begin{array}{l}\text { Olympiakos? X... - tylko tyle miał do powiedzenia Jarosław } \\
\text { Kołakowski }\end{array}$ & 1 & & & + \\
\hline 43 & $\mathrm{R}$ & $\begin{array}{l}\text { „Olympiakos? X...” - tylko tyle miał do powiedzenia Jarosław } \\
\text { Kołakowski }\end{array}$ & 1 & & & + \\
\hline 44 & $\mathrm{R}$ & „Olympiakos? X...”- tyle miał do powiedzenia Jarosław Kołakowski & 1 & & & + \\
\hline 45 & $\mathrm{R}$ & $\begin{array}{l}\text { „X” - tak rzecznik Ministerstwa Spraw Wewnętrznych odpowiada na } \\
\text { pytanie o prawdziwość doniesieñ (...) }\end{array}$ & 2 & & & + \\
\hline 46 & $\mathrm{R}$ & $\begin{array}{l}\text { „X”- odpowiadali zgodnie Tenczyński i Frydrychowicz pytani, czy } \\
\text { spotkali się. }\end{array}$ & 2 & & & + \\
\hline 47 & $\mathrm{R}$ & Tajemniczo zabrzmiała również odpowiedź (...): - X & 1 & & & 0 \\
\hline 48 & $\mathrm{R}$ & $\begin{array}{l}\text { (...) próbował podłączyć się do tej inicjatywy, dwuznaczną } \\
\text { odpowiedzią „X” }\end{array}$ & 1 & & & 0 \\
\hline 49 & $\mathrm{R}$ & X. (...) W szystko wyjaśni się w nocy - mówi & 1 & $\mathrm{X}$ & & \\
\hline
\end{tabular}




\begin{tabular}{|c|c|c|c|c|c|c|}
\hline 50 & $\mathrm{R}$ & $\begin{array}{l}\text { za tydzień (piątek; godz. 20), miał ponownie zagościć na } \\
\text { Łazienkowskiej telebeam. }-\mathrm{X}-\text { mówi nam Piotr Strejlau, rzecznik } \\
\text { prasowy Legii. }\end{array}$ & 1 & & & + \\
\hline 51 & $\mathrm{R}$ & $\begin{array}{l}\text { Czy to bedzie Kedziora? X. Nazwisko szkoleniowca podam W } \\
\text { poniedziałek po podpisaniu umowy }\end{array}$ & 1 & & & + \\
\hline 52 & $\mathrm{R}$ & X. Ale wie pan, w każdej plotce jest cząstka prawdy & 8 & & & + \\
\hline 53 & $\mathrm{R}$ & $\mathrm{X}$, pracujemy nad tym & 1 & & & + \\
\hline 54 & $\mathrm{R}$ & $\begin{array}{l}\begin{array}{l}\text { Prezydent nie zaprzecza. } \mathrm{X}- \\
\text { skomentował nasze informacje o (...) }\end{array} \\
\end{array}$ & 2 & & & + \\
\hline 55 & $\mathrm{R}$ & $\mathrm{X}$ - skomentował ten fakt & 1 & & & 0 \\
\hline 56 & $\mathrm{R}$ & X. Cała sprawa dopiero się rozkręca. & 1 & & & $+>$ \\
\hline 57 & $\mathrm{R}$ & X. Jutro i pojutrze „Czas” ukaże się na pewno. Reszta jest milczeniem. & 1 & & & $-’$ \\
\hline 58 & $\mathrm{R}$ & $\begin{array}{l}\text { X - ucina krótko [czlowiek, któremu prawo nakazuje apolitycznośćc. } \\
\text { gdy pytamy go, czy postanowił wrócić na lokalną scenę polityczną }\end{array}$ & 2 & & & + \\
\hline 59 & $\mathrm{R}$ & $\begin{array}{l}\text { Jednak Chińskie MSZ milczy. „X”- usłyszeliśmy w wypowiedzi } \\
\text { rzecznika Ministerstwa Spraw Wewnętrznych. }\end{array}$ & 1 & $\mathrm{X}$ & & \\
\hline 60 & $\mathrm{R}$ & X. Wszystko zadecyduje się jutro & 2 & & $\mathrm{X}$ & \\
\hline 61 & $\mathrm{R}$ & $\begin{array}{l}\text { Działacze sosnowieckiego klubu też nie chcą komentować ewentualnej } \\
\text { fuzji: - X }\end{array}$ & 1 & & & + \\
\hline 62 & $\mathrm{R}$ & Początkowo MON nabrał wody w usta, posługując się formułą: „X”. & 1 & & & $+>$ \\
\hline 63 & $\mathrm{R}$ & $\begin{array}{l}\text { X. Rzeczywiście mam kilka ofert i jadę na rozmowy, ale gdzie nie } \\
\text { zdradzę. }\end{array}$ & 1 & & & + \\
\hline 64 & $\mathrm{R}$ & X. Na razie nie chcę się na ten temat wypowiadać. & 1 & $\mathrm{X}$ & & \\
\hline 65 & $\mathrm{R}$ & $\begin{array}{l}\text { Natomiast że to jest coś wiecej niż plotka, że ma znaczne } \\
\text { prawdopodobienstwo prawdy, świadczy o tym fakt, że kiedy to ja tak } \\
\text { chlapnąłem i to powiedziałem, to zapytano prezesa Radia RMF FM i } \\
\text { on nie potw... powiedział: X, co, prawda, obiegowo oznacza no takie } \\
\text { stabe potwierdzenie, czyli przypuszczalnie to jest prawda. }\end{array}$ & 1 & & & + \\
\hline 66 & $\overline{\mathrm{I}}$ & $\mathrm{X}$ & 20 & & & 0 \\
\hline 67 & $\mathrm{I}$ & X ponieważ ta operacja jest w stanie realizacji. & 1 & & $\mathrm{X}$ & \\
\hline 68 & I & $\begin{array}{l}\text { Nie zastosuję formuły: X. Odmawiam jakiejkolwiek odpowiedzi w } \\
\text { sprawie, w której mogą być postawione prokuratorskie zarzuty. }\end{array}$ & 9 & $\mathrm{X}$ & & \\
\hline 69 & I & $\begin{array}{l}\text { X. Nie zostało to udowodnione, a prokuratura takiego zarzutu nie } \\
\text { postawiła. }\end{array}$ & 1 & & & $+{ }^{\prime}$ \\
\hline 70 & I & $\begin{array}{l}\text { Pan to powiedział. Ja X. I proszę nie wyciągać z tego żadnych } \\
\text { wniosków, jak klasyk kiedyś mówił. }\end{array}$ & 1 & & & $+{ }^{\prime}$ \\
\hline 71 & $\mathrm{I}$ & - X. (śmiech) /- To znaczy, że tak. Dziękuję. & 1 & & & + \\
\hline 72 & $\mathrm{I}$ & Czy te informacje są prawdziwe? / X & 1 & & & 0 \\
\hline 73 & $\mathrm{I}$ & $\begin{array}{l}\text { Ja X i nie zamierzam tego zrobić w najbliższym czasie. Ja Pani nie } \\
\text { powiem, czy rząd polski miał takie informacje, ale powtarzam, że rząd } \\
\text { polski ma wystarczające informacje. / Ale Amerykanie potwierdzaja. } \\
\text { Nie, żaden oficjalny czynnik nie potwierdził i nie zaprzeczył tej } \\
\text { informacji. }\end{array}$ & $\begin{array}{l}1 \\
* \\
2\end{array}$ & & & + \\
\hline 74 & $\mathrm{I}$ & [sprawy się pokomlikowały] Tak więc X. & 1 & & & 0 \\
\hline 75 & I & $\begin{array}{l}\text { Na to pytanie nie udzielę odpowiedzi. Powiem za to wymijająco jak } \\
\text { kiedyś mówił w TVN'owym Agencie grubszy koleś. „X!” }\end{array}$ & 1 & & & + \\
\hline 76 & I & $\begin{array}{l}\text { Wydałeś płytę, jesteś zadowolony z zarobionych na niej pieniędzy? / } \\
\text { X, nie narzekam :-) }\end{array}$ & 2 & & & + \\
\hline 77 & $\mathrm{~W}$ & Nie potwierdzam niczego ani nie zaprzeczam & 1 & & & 0 \\
\hline 78 & $\mathrm{~W}$ & Nie potwierdzam tego że (...) ani nie zaprzeczam & 1 & & & + \\
\hline 79 & $\mathrm{~W}$ & $\mathrm{X}$ & 25 & & & 0 \\
\hline 80 & W & $\mathrm{X}$ & 2 & $\mathrm{X}$ & & \\
\hline 81 & $\mathrm{~W}$ & X. Jedyne, co teraz moge powiedzieć, to ... & 2 & $\mathrm{X}$ & & \\
\hline 82 & W & $\begin{array}{l}\text { Na wszystkie pytania redakcyjne chciałoby się odpowiedzieć } \\
\text { dyplomatycznie: X. Ale mimo lekkiego przestraszenia polityczna } \\
\text { poprawnością spróbuję być szczery. Czy artysta potrzebuje Kościoła? } \\
\text { Oczywiście - tak! }\end{array}$ & 1 & & & + \\
\hline 83 & $\mathrm{~W}$ & $\begin{array}{l}\text { X. Prowadzimy wiele projektów i trakcie trwania negocjacji nie } \\
\text { informujemy o nich. }\end{array}$ & 2 & $\mathrm{X}$ & & \\
\hline 84 & W & Owo - X - ciągnęło się przez kilka miesięcy. & 1 & & & 0 \\
\hline
\end{tabular}




\begin{tabular}{|c|c|c|c|c|c|c|}
\hline 85 & $\mathrm{~W}$ & X spekulacjom prasowym. & $\mid 1$ & & & 0 \\
\hline 86 & $\mathrm{~W}$ & $\mathrm{X}$ tej informacji mówił. & 1 & & & 0 \\
\hline 87 & W & $\begin{array}{l}\text { - Za wszelką cenę należy unikać ucieczki, krycia się, odpowiadania: } \\
\text { „Bez komentarza”, „X”, „Nie mam nic do powiedzenia” itp. } \quad \text { /jak } \\
\text { udzielać wywiadu z zaskoczenia/ }\end{array}$ & 4 & & & 0 \\
\hline 88 & $\mathrm{~W}$ & $\mathrm{X}$, bo normalnie nie pamiętam & 1 & & $\mathrm{X}$ & \\
\hline 89 & $\mathrm{~W}$ & Tego, czy (...) nie pamiętam - „X” & 2 & & $\mathrm{X}$ & \\
\hline 90 & W & $\begin{array}{l}\text { Przeżyliśmy ponoć tylko dzięki temu, że on chwycił za kierownicę, X, } \\
\text { bo wlasny atak śmiechu mnie zdekoncentrowal. }\end{array}$ & 2 & & $\mathrm{X}$ & \\
\hline 91 & W & A jeśli chodzi o Andrzeja, mogę tylko dyplomatycznie stwierdzic: X. & 2 & $\mathrm{X}$ & & \\
\hline 92 & $\mathrm{~W}$ & $\begin{array}{l}\text { Dla dobrego reportera rzecznik jest co najwyżej świadkiem na końcu } \\
\text { listy, który ma wygłosić nieśmiertelna formułe „X” albo pokrewny } \\
\text { banał. }\end{array}$ & 1 & $\mathrm{X}$ & & \\
\hline 93 & W & ...takom przyzwoito ze mnie robiu.... a ja X.... & 1 & & & 0 \\
\hline 94 & W & Twierdzi że jest przystojny $-\mathrm{X} \ldots$...)) & 1 & & & 0 \\
\hline 95 & W & $\begin{array}{l}\text { Jeśli powiedziała: „X”...to chyba znaczy że jest Marta z Mariuszem.... } \\
\text { a w ogóle to widac... w telewizji...nic przed nami nie ukryjesz }\end{array}$ & 1 & & & + \\
\hline 96 & W & $\begin{array}{l}\text { Chińczycy wierzyli w moc jadłospisu, który miał przynosić "dobrą } \\
\text { aurę erotyczną". X, ale w kregach europejskich moc w tych sprawach } \\
\text { przypisuje się się raczej agatowi. }\end{array}$ & 2 & & & - \\
\hline 97 & W & $\begin{array}{l}\text { (...), Jeden do publicznego oświadczenia: "X", (...) [ [zart - ilu } \\
\text { specjalistów PR potrzeba do wymiany żarówki] }\end{array}$ & 1 & & & + \\
\hline 98 & W & $\begin{array}{l}\text { A może po prostu jestem ciemny ... } \\
\text { nie za-przeczam } \\
\text { ułomności : } 11:]\end{array}$ & 1 & & & - \\
\hline 99 & $\mathrm{~W}$ & Nie chodzi o klub z Wrocławia. / Czy Pruszków? / X & 1 & & & + \\
\hline 100 & $\mathrm{~T}$ & $\mathrm{X}$ & 3 & & & 0 \\
\hline 101 & $\mathrm{~T}$ & Ja nie wiem, jak będę stał $\mathrm{z}$ robotą $X$ & 3 & & $\mathrm{X}$ & \\
\hline 102 & $\mathrm{~T}$ & $\begin{array}{l}\text { X...-) Do przyszłego tygodnia musi to pozostać tajemnica, bo jeszcze } \\
\text { nie wszystko jest pewne. Ale już niedługo będziemy o tym } \\
\text { informować. }\end{array}$ & 1 & & & + \\
\hline 103 & $\mathrm{~T}$ & $\begin{array}{l}\text { X ... coś bym i może powiedziała, ale czytają to nieletni, a nie chce } \\
(\ldots)\end{array}$ & 1 & $X$ & & \\
\hline 104 & $\mathrm{~S}$ & Mówisz do Harona: $\mathrm{X}$. & 1 & & & 0 \\
\hline
\end{tabular}

Tabela 8. Analiza logiczna tekstów z fraza „,nie zaprzeczam, nie potwierdzam” (z ewentualnymi wtraceniami)

\begin{tabular}{|c|c|c|c|c|c|c|}
\hline Lp. & typ & tekst & ile & WNP & NW & ? \\
\hline 1 & $\mathrm{~T}$ & $\mathrm{X}$ & 5 & & & 0 \\
\hline 2 & I & $\begin{array}{l}\text { X. Proszę nie oczekiwad́ ode mnie odpowiedzi na te kłopotliwe } \\
\text { pytania. }\end{array}$ & 1 & $\mathrm{X}$ & & \\
\hline 3 & I & $\begin{array}{l}\mathrm{X} \text {. W służbach obowiazuje stara angielska zasada - o nazwiskach się } \\
\text { nie mówi. }\end{array}$ & 1 & $\mathrm{X}$ & & \\
\hline 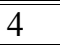 & $\mathrm{O}$ & $\bar{X}$ & 2 & & & 0 \\
\hline 5 & $\mathrm{O}$ & Odpowiem dyplomatycznie. $\mathrm{X}, \mathrm{z}$ naciskiem na to pierwsze. & 4 & & & - \\
\hline 6 & $\mathrm{~W}$ & $\mathrm{X}$ & 5 & & & 0 \\
\hline 7 & W & Cóż...X & 1 & $\mathrm{X}$ & & \\
\hline 8 & W & Jedno jest pewne $\mathrm{X}$ & 1 & & & 0 \\
\hline 9 & W & $\mathrm{X}$, pierwszy raz stysze. & 1 & & $\mathrm{X}$ & \\
\hline 10 & W & $\begin{array}{l}\text { Ja naprawdę nie moge jeszcze niczego ujawnić. Jednak z Anglią -X. } \\
\text { Wciąż prowadzone są rozmowy i wszystko może zmienić się... }\end{array}$ & 1 & & & + \\
\hline 11 & W & $\begin{array}{l}\text { Ja naprawdę nie moge jeszcze niczego ujawnić. Z Anglia X. Wciąż } \\
\text { prowadzone są rozmowy i wszystko może zmienić się... }\end{array}$ & 1 & & & + \\
\hline 12 & W & $\begin{array}{l}\text { Czy będą zmiany w innych spółkach nie wykluczam. X. Po prostu } \\
\text { będzie to wynikało na Walnych Zgromadzeniach, ... }\end{array}$ & 1 & & & $+t^{\prime}$ \\
\hline 13 & $\mathrm{~W}$ & ...nie zaprzeczam tej teoril, ani nie potwierdzam ... & 6 & & & + \\
\hline 14 & $\mathrm{R}$ & $\mathrm{X}$ & 17 & & & 0 \\
\hline
\end{tabular}




\begin{tabular}{|c|c|c|c|c|c|}
\hline 15 & $\mathrm{R}$ & $\mathrm{X}$ tego. & 1 & & 0 \\
\hline 16 & $\mathrm{R}$ & X mówi. Wiem tylko, że ... & 1 & & 0 \\
\hline 17 & $\mathrm{R}$ & X tej informacji, wszystko się wyjaśni w dniu składania ofert. & 2 & & 0 \\
\hline 18 & $\mathrm{R}$ & $\mathrm{X}$ i proszę nie wyciągać z tego żadnych wniosków. & 2 & & 0 \\
\hline 19 & $\mathrm{R}$ & $\begin{array}{l}\text { Oficer dyżurny policji zachował się jak skończony dyplomata: X. } \\
\text { Funkcjonariusz thumaczyl, że w tym samym czasie wydarzył się ... }\end{array}$ & 2 & $\mathrm{X}$ & \\
\hline 20 & $\mathrm{R}$ & $\begin{array}{l}\text { Panie pośle, nie, dlatego że ja X. Ta fraza w ogóle mnie brzydzi, bo } \\
\text { jest taka dość historycznie skompromitowana. Po raz pierwszy jej w } \\
\text { życiu używam. }\end{array}$ & 4 & & 0 \\
\hline
\end{tabular}

Przy analizie tych wypowiedzeń, autor niniejszego artykułu założył, że teksty tu odnoszą się do wcześniejszego stwierdzenia pozytywnego.

Poniższe tabele 9 i 10 są zestawieniem znaczeń wyrażeń z poprzednich dwóch tabel (przy czym znaczek „,+ zastępuje dotychczasowe dwa znaczki: „," i „,+”), a tabela 11 przedstawia sumę wyników z tabel 9 i 10.

Tabela 9. Podsumowanie wyników z Tabeli 7

\begin{tabular}{|l||r|r|r|r|r||r||}
\hline & WNP & NW & 0 & + & - & \multicolumn{1}{l|}{ SUMA } \\
\hline \hline T & 1 & 3 & 3 & 1 & & 8 \\
\hline I & 9 & 1 & 22 & 8 & & 40 \\
\hline O & 13 & 11 & 14 & 22 & 2 & 62 \\
\hline W & 9 & 5 & 35 & 5 & 3 & 57 \\
\hline R & 7 & 8 & 97 & 39 & 1 & 152 \\
\hline S & & & 1 & & & 1 \\
\hline \hline SUMA & 39 & 28 & 172 & 75 & 6 & 320 \\
\hline \hline \% z 320 & 12,2 & 8,8 & 53,8 & 23,4 & 1,9 & 100 \\
\hline $\begin{array}{l}\text { \% bez 0 } \\
\text { (tj. z 148) }\end{array}$ & 26,4 & 18,9 & & 50,7 & 4,0 & 100 \\
\hline
\end{tabular}

Tabela 10. Podsumowanie wyników z Tabeli 8

\begin{tabular}{||l||r|r|r|r|r||r||}
\hline \hline & WNP & NW & 0 & + & - & SUMA \\
\hline \hline T & & & 5 & & & 5 \\
\hline I & 2 & & & & & 2 \\
\hline O & 1 & 1 & 6 & 9 & & 17 \\
\hline R & & 2 & 27 & & & 29 \\
\hline R & & & & & & \\
\hline S & 3 & 3 & 40 & 9 & 4 & 59 \\
\hline \hline SUMA & 5,1 & 5,1 & 67,8 & 15,3 & 6,8 & 100 \\
\hline \hline \% z 59 & 15,8 & 15,8 & & 47,4 & 21,0 & 100 \\
\hline $\begin{array}{l}\text { \% bez 0 } \\
\text { (tj. z 19) }\end{array}$ & & & & & & \\
\hline
\end{tabular}

Tabela 11. Zsumowanie wyników z tabel 9 i 10

\begin{tabular}{|l||r|r|r|r|r|r||}
\hline & WNP & NW & \multicolumn{1}{l|}{ l } & \multicolumn{1}{l|}{ - } & \multicolumn{1}{l|}{ SUMA } \\
\hline \hline T & 1 & 3 & 8 & 1 & & 13 \\
\hline I & 11 & 1 & 22 & 8 & & 42 \\
\hline O & 13 & 11 & 16 & 22 & 6 & 68 \\
\hline W & 10 & 6 & 41 & 14 & 3 & 74 \\
\hline R & 7 & 10 & 124 & 39 & 1 & 181 \\
\hline S & & & 1 & & & 1 \\
\hline \hline SUMA & 42 & 31 & 212 & 84 & 10 & 379 \\
\hline
\end{tabular}




\begin{tabular}{||l||r|r|r|r|r||r||}
$\begin{array}{l}\% \text { z } 379 \\
\text { \% bez 0 }\end{array}$ & 11,1 & 8,2 & 55,9 & 22,2 & 2,6 & 100 \\
(tj. z 167) & & 18,6 & & 50,3 & 6,0 & 100 \\
\hline
\end{tabular}

W tabelach tych omówienia wymagają jeszcze tylko ostatnie 2 ich wiersze. Otóż:

- przedostatni wiersz określa, jakim procentem wszystkich rozpatrywanych w tabeli wyników są te, które umieszczone są w danej jej kolumnie,

- ostatni wiersz określa, jakim procentem wszystkich rozpatrywanych w tabeli wyników są te, które umieszczone są $\mathrm{w}$ danej jej kolumnie, jednak $\mathrm{z}$ pominięciem tych, które wyszczególnione zostały w kolumnie „0”.

Spróbujmy wyciaggnąć stosowne wnioski $\mathrm{z}$ tych tabel. W tym celu, wyróżnione $\mathrm{w}$ nich (ciemnym tłem) liczby ujmijmy w jednej tabeli:

Tabela 12. Zestawienie istotnych wyników z tabel 9 - 11

\begin{tabular}{|l|l|c||c|c|c|c|r||}
\hline Lp. & typ tekstu & rozpatrywany w tabelach & \multicolumn{1}{l|}{ WNP } & NW & + & - \\
\hline \hline 1 & nie potwierdzam, nie zaprzeczam & $7 \mathrm{i} 9$ & 53,8 & 26,4 & 18,9 & 50,7 & 4,0 \\
\hline 2 & nie zaprzeczam, nie potwierdzam & $8 \mathrm{i} 10$ & 67,8 & 15,8 & 15,8 & 47,4 & 21,0 \\
\hline 3 & OBA POWYŻSZE & 11 & 55,9 & 25,1 & 18,6 & 50,3 & 6,0 \\
\hline
\end{tabular}

Widzimy z niej, że wiersz 1 i 3 są prawie identyczne, a wiersz 2 różni się od nich znacząco. Analizę wiersza 3 możemy pominąć, jako że:

- jest on prawie identyczny z wierszem nr 1 ,

- a do uogólnionej analizy konkretnej sytuacji lepiej jest (ze względu na wiarygodność) posłużyć się właściwym dla niej wierszem nr 1 lub 2.

Tak więc,

- w sytuacjach z 1 . wiersza - w ponad co drugim przypadku,

- $\quad$ w sytuacjach $\mathrm{z} 2$. wiersza - w ponad $2 / 3$ przypadkach,

trudno jest określić, czy wypowiadająca daną sekwencję osoba wie, czy też nie wie to, o czym mówi (kolumna „0”).

Biorąc pod uwagę pozostałe sytuacje (tj., gdy możemy coś powiedzieć na temat tak enigmatycznie przedstawionej sytuacji), mamy następujący (składający się do $100 \%$ ) rozkład wyników:

a) w obu sytuacjach, mniej więcej w 50 \%-ach możemy wydedukować, że jednak „coś jest na rzeczy” (tj. że odpowiedź jest pozytywna - patrz kolumna „,"),

b) „że tak nie jest” możemy wydedukować zdecydowanie częściej w 2. niż w 1. sytuacji (w stosunku 21:4 - kolumna „,"); tak więc zaczynając stwierdzenie od nie zaprzeczam które rzadziej występuje niż zaczynające się od nie potwierdzam, częściej się zaprzecza niż w drugim z tych przypadków,

c) wobec (w przybliżeniu) równej liczby procent odpowiedzi na TAK (sytuacja a)), a „Zawładnięcia” dużej liczby procent przez odpowiedź na NIE tekstu 2. typu, a małej liczby procent tekstu 1. typu (sytuacja b)), na pozostałe dwie sytuacje (WNP i NW), mniej procent mamy do rozkładu w sytuacji 2. (gdzie rozkładają się one po równo po ok. $16 \%$ ), a więcej w sytuacji 1. (gdzie z kolei dysponujemy w sumie $45 \%$-ami, które rozkładają się mniej więcej w stosunku $3: 2$ na korzyść WNP, a na niekorzyść sytuacji NW).

Powracając do analizy tabel 9 - 11, można jeszcze dopowiedzieć, że biorąc pod uwagę typ wypowiedzeń (T, I, O, W, R i S), nie odgrywa on większej roli przy analizie znaczenia naszych enigmatycznych stwierdzeń. Właściwie można w tej kwestii jedynie dodać, że odpowiedzi na NIE pojawiły się jedynie w przypadku O, W, R (a więc nigdy w T, R i S). 